Article

\title{
Volunteer Tourism as a Sustainable Form of Tourism-The Case of Organized Events
}

\author{
Kristína Pompurová, Radka Marčeková *, L'ubica Šebová, Jana Sokolová and Matej Žofaj \\ Faculty of Economics, Matej Bel University, Tajovského 10, 97590 Banská Bystrica, Slovakia; \\ kristina.pompurova@umb.sk (K.P.); lubica.sebova@umb.sk (L'.Š.); jana.sokolova@umb.sk (J.S.); \\ matej.zofaj@umb.sk (M.Ž.) \\ * Correspondence: radka.marcekova@umb.sk; Tel.: +421-48-446-2217
}

Received: 3 March 2018; Accepted: 4 May 2018; Published: 8 May 2018

\begin{abstract}
This paper focuses on volunteer tourism as a sustainable form of tourism relating to the volunteer service at a tourism destination and specific tourism activities. The aim of the paper is to explore volunteer tourism in Slovakia with examples of organized events, especially to search exactly how event's organizers support the development of domestic and inbound volunteer tourism in Slovakia. This paper is based on a sociological survey. We addressed 653 heterogeneous event's organizers in Slovakia. $18 \%$ of them participated in the questionnaire survey. The collected data were processed by selected mathematical and statistical methods in SPSS statistics program. As such, we found most events organizers team up with volunteers. Only half of the organizers cooperate with local volunteers, while the second half also support the development of volunteer tourism engaging in voluntourism. In the case of attractive events, the engagement of voluntourists could be more effective. The current situation has resulted from missing information about the management of volunteers but it could be improved through an e-manual for event organizers providing an outline guide for volunteer management.
\end{abstract}

Keywords: volunteer tourism; event volunteering; event's organizers; volunteers; voluntourists

\section{Introduction}

Over the past several decades, tourists from high-income countries have increasingly turned to alternative forms of travel that deliver rewarding experiences and promise sustainable development of destinations that [1] link the needs of the present without compromising the ability of future generations to meet their own needs [2]. The unique motivation of young travelers (nowadays represented by Generation Y) makes this niche particularly important for the key goals of the global tourism agenda, by which United Nations' organizations, including the UNWTO, support the three-pillar (environmental, socio-cultural, and economic) concept of sustainable tourism [3]. This concept proposes an ideal situation in which there exists a balance among all the three dimensions [4] and according to the United Nations, young people are recognized as the main force of development and social change that has the potential to drive sustainable development in the tourism industry [5]. Data from the UNWTO and the WYSE Travel Confederation highlight the current and future importance of young tourists [6]. Youth travel has become one of the fastest growing segments of international tourism, representing more than $23 \%$ of the over one billion tourists traveling internationally each year [5]. This situation has created a strong interest in examining the attitudes, values or behavior of the current young generation of travelers called Generation $Y$ (e.g., [7]). Youth travelers are travelling more frequently to a wider range of destinations, looking for more cultural and social experiences, interested more in outdoor and sports activities, music-related events, and social and environmental impacts of travel, increasing their use of the Internet for travel information and booking, spending their holidays focused on personal indulgence, shopping, and fine 
dining [8]. In the light of these observations, it could be debatable if Generation $Y$ has a positive impact on sustainable development of tourism. However, recent research on the interest, attitudes, travel motivation, and behavior towards sustainability [6] confirm young people's interest in certain dimensions of sustainability. This generation rejects the limitations of the impersonal, non-interactive system of mass tourism and instead of that, show social and environmental awareness, interest in environmentally-oriented activities, locally-produced goods and services, as well as an interest in a variety of experiences, self-improvement, and experiments, which reflect a need for authentic holiday experiences. The positive attitudes towards diversity, flexibility, and social issues-as an increasing level of concern over the impacts of travel and strong desire to experience local culture-is reflected for example in the interest of Generation $Y$ travelers in volunteer tourism [8]. It is Generation $Y$ who has a growing share in the development of volunteer tourism [9].

Volunteer tourism (also called voluntourism) is one of the fastest growing examples of alternative travel experiences respecting dimensions of sustainable tourism. It creates decommodified experiences that move the goals of tourism away from for-profit forms of escapism towards something that will place social, cultural, and ecological value on local environments and communities [10]. According to the available literature [11-14] volunteer tourism can be characterized as an integrated organized combination of volunteer service at tourist destination and specific tourism activities, which are performed in one's spare time, out of a place of residence, in home country or abroad and that is beneficial not only for voluntourists, but also for local communities and the environment. As Wearing and McGehee argue [14], the increase in this type of tourism has been explored by a number of authors. Volunteer tourism research seems to be following the same four phases of study as mainstream tourism, which includes advocacy, cautionary, adaptancy, and scientific platforms.

This paper focuses on volunteer tourism as a sustainable form of tourism by using the example of organized events in Slovakia. It searches how event organizers support the development of domestic and inbound volunteer tourism in Slovakia. The overarching objectives of the study are to identify:

1. what the perception of volunteers and the level of cooperation between the volunteers and events' organizers in Slovakia is;

2. what the degree of professionalization of work with volunteers at events in Slovakia is;

3. how event organizers contribute to the development of domestic and inbound volunteer tourism in Slovakia;

4. how organizers apply selected parts of voluntourist management.

To this end, the study objectives are addressed by drawing upon the opinions of heterogeneous event organizers in Slovakia. As such, an analysis of recently collected data around organizers' views is examined, and the contribution of events to the sustainability of tourism is discussed.

\section{Literature Review}

The growth and development of the volunteer tourism market has caused a combination of volunteering and tourism in various forms of practice. It has now progressed into a macroniche with an array of micro niches situated beneath it [15]. Despite this, available studies mostly explore environmental, humanitarian, and development projects in less developed countries, whose cultures are significantly different from voluntourists' cultures $[14,16]$. However, the perception of volunteer tourism as a combination of travel and volunteering only in developing countries is short-sighted and too simplistic owing to the diverse array of opportunities available in today's market. Voluntourism projects in developed countries [17] are becoming more and more popular and as volunteering in developing countries, it includes the different segments-teaching, marine work, conservation, research, and so forth. Uriel, Reichen, and Ron [18]; Holmes et al. [19]; Lyons and Wearing [20]; and also Mwaruta [17] argue that also voluntourists in domestic tourism should not be forgotten. These voluntourists, who the current body of research has neglected, volunteer in the country of their usual residence. According to Holmes et al. [19] domestic volunteer tourism includes volunteering in museums and 
heritage attractions; in tourist information centres; parks, recreation, and conservation; and event volunteering as well.

Most voluntourism projects are usually organized by non-governmental organizations, local groups, clubs or associations, and local authorities, which are also called the third, non-governmental, non-profit, or voluntary sector [21]. These organizations play an important role in specific areas of the tourism industry. They do not perceive it as the activities associated with the satisfaction of the needs of holidaymakers, instead they see tourism as an opportunity to create new, positive values and activities for tourists as well as local communities [10]. At the same time, non-governmental organizations better reflect the specific problems and requirements of the communities [22] and help to create targeted activities and projects. However, the volunteer tourism marketplace is ever evolving and in recent years we have seen new businesses entering the market. A significant increase in the number of commercial operators has changed the face of the industry and the discussion about real benefits of volunteer tourism have appeared (e.g., [23-27]). These profit-oriented organizations have usually the opposite impact on communities than non-profit organizations [14]. In a business sense, their priority is attracting voluntourists rather than the impact that they have on host communities [23]. Research from Leeds Metropolitan University has revealed that volunteer tourism organizations offering the most expensive products are likely to be the least responsible in relation to host communities [28]. However, the status of the organization is no guarantee of responsible practice [29]. Even in the non-profit sector, despite good intentions, organizations may fail to consider local needs and priorities due to 'top-down planning', creating dependency and hurting a destination's entrepreneurship and community [30]. If the organization presented itself as the volunteer tourism organization, it does not mean that its activities are positive and decrease the negative impact of mass tourism. Because of that, the sustainable and responsible approach in managing volunteer tourism activities in all their forms is needed.

In this study, we focus on event volunteering as the part of volunteer tourism. Event volunteering involves various forms of volunteerism, e.g., international, formal, informal, episodic, occasional, long-term, and short-term. Although some organizations hire volunteers for full-year positions, most volunteers take part in occasional events to ensure the running of the event [31]. The volunteer's commitment does not only support the success of the events, but increases the potential of a place as a tourism destination, too.

The number of mostly young people who want to acquire new skills and experiences through volunteering is growing [32-35]. Motives for volunteering in events are analogical with generalized motives of volunteer tourism, although depending on the type of event they reflect rather non-altruistic motifs. The motivation for a volunteer to attend an event is the opportunity to meet new people and create new friendships, to gain new skills and perspectives of life, to get free tickets and access to an event, to get promotional materials or even clothing with the event's logo for free, to help the community surrounding the event, or the opportunity to meet celebrities participating in the event $[31,36]$.

Simultaneously, the number of event organizers, who benefit from cooperation with volunteers or are even dependent on volunteers, is also growing. Apart from the fact that volunteers helping organizers for example to optimize the personnel costs of an event or reduce the environmental burden of the event, the organizing team is enriched with their enthusiasm, skills, and sense of duty towards the community that in general contributes to the satisfaction of visitors [37-39]. Therefore, many event organizers consider volunteers as the key part of the successful event. By engaging volunteers, they take on the selected task of receiving volunteer tourism organizations.

The growing trend of event volunteering has an impact on the work of the researchers who carry out a number of projects in this field. Studies are mostly focused on motivation, experiences, and satisfaction of volunteers and management of volunteers in various types of events-e.g., cultural and art festivals; religious festivals; special events-but most dominate studies focused on sport events [31,40-44]. Although such research focus is narrowly specified, increasing interest of the 
distinct fields of study in events, event tourism and volunteering, make a good environment for future research. Gaps in current literature of event tourism as well as event volunteering and the future research trends could be highlighted [45-47] such as with: (1) examination of the interaction and partnerships between the people, processes, and resources that are key to their initiation and successful development of events; (2) expanding current studies and exploring the differences in motivations, experiences, and impacts over time; (3) extending the knowledge about sustainability of events and theoretical and practical approaches of responsible management to event tourism.

In order to maintain positive attitudes to alternative tourism forms for young generations, who are a major part of volunteers at events, it is necessary to examine not only the interaction between event organizers and the wider volunteering infrastructure, but also explore some important attitudes over time. In this concept, research has emerged that is examining how event volunteers could be encouraged to sustain their efforts and volunteer again at similar events or in the community after the event (volunteering legacy) [48]. The results from the study of post-event volunteering legacy on a sample of London 2012 Olympic Games volunteers suggest that the overall experience with the Games did little to inspire a wider volunteering legacy. Although we assume that this conclusion cannot be generalized to all events, because of the specific character of the event (e.g., occasional mega-event), we agree that the volunteering legacy outcome depends on a number of factors including the planning phase, design, and implementation for a legacy as well as the existing policy environment and the support or training available to volunteers [48], i.e., responsible event (volunteer) management.

\section{Materials and Methods}

\subsection{Aim and Material}

The aim of the research is to explore volunteer tourism in Slovakia with the example of organized events, especially to examine how event's organizers support the development of domestic and inbound volunteer tourism in Slovakia.

Based on the information from internet portals where potential visitors can get information about events in Slovakia (www.allfestivals.com, www.nafestival.sk, www.dikymoc.sk, www.folklorfest.sk, www.ludovakultura.sk), websites of local and regional tourism organizations and other selected institutions (www.culture.gov.sk, www.nocka.sk, www.matica.sk, www.sport.iedu.sk) an event organizers' database was created. Gathering information for the database was complicated by the fact that none of the websites contained a comprehensive list of events or their organizers (it was necessary to remove any duplicates), and that most available portals contained little information about the event (most often in a form of leaflet or short note) without any information about the organizer (it was necessary to do additional searches for individual event websites or social network sites). Therefore, we assume there is a need to coordinate the list of organized events in Slovakia.

The primary data was obtained through a questionnaire survey. 653 event organizers from the database were addressed by e-mail in 2017. Questionnaires had a return rate of $18.10 \%$ (118 completed the questionnaires). This was possibly caused by the way these questionnaires were distributed and the lack of time for event organizers. Gained data were processed by selected mathematical-statistical methods in the statistics program SPSS Statistics. Statistical tests have been evaluated using a 95\% probability level.

\subsection{Analysis of Sample Profile}

Nearly two-thirds (65.30\%) of respondents were from the public sector, a fifth $(19.50 \%)$ were from non-profit sector and only $15.30 \%$ were from the private sector. Given the absence of background information, it was not possible to determine whether the results of this research were representative or significantly affected by the rate of a willingness of the event organizers to respond to the questions. 
One-quarter $(24.60 \%)$ of respondents reported event organizing as their main activity, $59.30 \%$ as an equal share of the organization's activities and only $16.10 \%$ as an activity which they are devoting to marginally.

While $66.90 \%$ of respondents regularly organize (at least once a year) several thematically diverse events, $19.50 \%$ concentrate on organizing numerous homogeneous events, $10.20 \%$ organize only one event on a regular basis, and $3.40 \%$ of respondents organize events only occasionally. This is typical, especially for the organizations which reported organizing events as a marginal activity.

A large number of these events were cultural events $(75.50 \%)$, which corroborate the results, from the study of the aggregate demand of Slovak inhabitants after organized events [49].

According to the estimation of event organizers, the events are attended by local residents as well as visitors from other regions. Most $(90.70 \%)$ of the organizations that participated in the research organize small events with less than 10 thousand participants, which is typical for events organized in Slovakia.

\section{Results}

\subsection{Cooperation with Volunteers}

As the first step, we have tried to find out if the events' organizers ever cooperate with volunteers.

Seven out of 10 respondents involved volunteers in the event's preparation and realization (32.20\% regularly and $37.30 \%$ occasionally) creating suitable conditions for the volunteer tourism development. Only a third (30.50\%) of respondents has not cooperated with volunteers, particularly because of a lack of information and experiences of volunteers' management. However, more than a half of them were interested in cooperation with volunteers, if there was an event organizer's manual providing an outline guide for managing the volunteers. The rest of respondents could not imagine the involvement of volunteers in organizing events, because of complicated procedures and regulations in the public sector.

Subsequently, 82 questionnaires were evaluated from the responses of the organizers who have involved volunteers in the organization of the events.

Due the size of events, an average number of volunteers involved in organizing the events (Table 1 ) are equitable. Most of organizations (87.80\%) cooperate with a maximum of 20 volunteers.

Table 1. Average number of volunteers involved in organizing the events.

\begin{tabular}{ccccc}
\hline Number of Visitor & Frequency & Percent & Valid Percent & Cumulative Percent \\
\hline 1 to 5 & 32 & 27.1 & 39.0 & 39.0 \\
6 to 10 & 22 & 18.6 & 26.8 & 65.9 \\
11 to 20 & 18 & 15.3 & 22.0 & 87.8 \\
21 to 50 & 7 & 5.9 & 8.5 & 96.3 \\
51 to 100 & 3 & 2.5 & 3.7 & 100.0 \\
Total & 82 & 69.5 & 100.0 & \\
Missing System & 36 & 30.5 & & \\
Total & 118 & 100.0 & & \\
\hline
\end{tabular}

The value of Spearman's coefficient (Sig. $=0.027$, Correlation Coefficient $=1000$ ) indicates that by increasing the scale of events also increases the number of volunteers involved in the preparation and realization phase of events.

Although a majority of events could be organized without the participation of volunteers, according to three-quarters of the addressed organizations, volunteers play an important role in making the events possible (Table 2). 
Table 2. The importance of volunteers in the events.

\begin{tabular}{ccccc}
\hline Status of Volunteers & Frequency & Percent & Valid Percent & Cumulative Percent \\
\hline Most important & 17 & 14.4 & 20.7 & 20.7 \\
Important & 46 & 39.0 & 56.1 & 76.8 \\
Unimportant & 19 & 16.1 & 23.2 & 100.0 \\
Total & 82 & 69.5 & 100.0 & \\
Missing System & 36 & 30.5 & & \\
Total & 118 & 100.0 & & \\
\hline
\end{tabular}

According to the ANOVA results (Sig. $=0.003, \mathrm{~F}=6379$ ), there is a significant difference between the perceptions of importance the volunteers' participation in event depending on the economic sector of the organization preparing the event. While huge number of volunteers help non-profit organizations, they are relatively less important to public sector organizations (Table 3). This could be caused by a fixed budget, which is set aside by the organizations (the absence of the need to reduce personnel costs by the event organization).

Table 3. The status of volunteers depending on the economic sector to which the organization preparing the event belongs.

\begin{tabular}{ccccc}
\hline \multirow{2}{*}{ Status of Volunteers } & \multicolumn{3}{c}{ Sector of Economy } & \multirow{2}{*}{ Total } \\
\cline { 2 - 4 } & Private Sector & Public Sector & Non-Profit Sector \\
\hline Most important & 18.18 & 12.00 & 42.86 & 17 \\
Important & 63.64 & 56.00 & 52.38 & 46 \\
Unimportant & 18.18 & 32.00 & 4.76 & 19 \\
Total & 11 & 50 & 21 & 82 \\
\hline
\end{tabular}

\subsection{Professionalization of the Work with Volunteers}

Because the effective involvement of the volunteers in the organization of the event requires a planned and organized process, the second part of the survey was focused on the level of professionalization of the work with volunteers. For most events $(79.30 \%)$, the selected member of the organizing team is responsible for the management of volunteers. Only a fifth of the organizations create the position of volunteer manager or coordinator. Volunteer managers may be paid employees (13.40\%), outsourcers with created job conditions and clearly defined labour content $(1.20 \%)$, or volunteers $(6.10 \%)$, for example an individual, who is not paid for his work.

According to the ANOVA results, there is no significant difference in the way volunteers are coordinated and the scale of the event (Sig. > 0.05).

The existence of the volunteer coordinator is the key element in the event management. A volunteer coordinator is the quality guarantor of the volunteer management. An example of good practice is the biggest Slovak music festival Pohoda (which is ranked by European Festival Awards each year as the best medium-sized European festival), where the volunteer coordinator has his own coordination team.

Every volunteer should be acquainted with the work he will be doing at the event. According to Brozmanova Gregorova et al. [50] it is important to clearly define and set up the needs, requirements, and obligations of volunteers. Volunteers should have specified activities or schedule of duties and ways of communicating. However, only $62.2 \%$ of the addressed organizations specify the workload of the volunteers (12.2\% in written form and $50 \%$ in oral). According to the ANOVA results (Sig. $=0.016, \mathrm{~F}=3658$ ), there is a significant difference in specifying the volunteer's tasks as it depends on the coordination. The workload is a matter of course in the case of creating a paid position for a volunteer manager. 


\subsection{Voluntourist Participation}

The development of volunteer tourism in the target destination depends on whether volunteers participating in the event are local residents or can be described as voluntourists. While half of addressed event organizers cooperate only with local residents, the other half also works with voluntourists and thereby encourage volunteer tourism development. The dependency on the size of the event was not statistically (ANOVA) demonstrated (Sig. > 0.05).

Next, the approximate share of voluntourists in a total number of volunteers was examined. Though, most respondents reported that the participation of voluntourists was minor (Table 4). Most $(78.0 \%)$ proclaimed that their share was, at most, $20 \%$.

Table 4. Voluntourists percentage of total number of volunteers.

\begin{tabular}{ccccc}
\hline Part of Voluntourists & Frequency & Percent & Valid Percent & Cumulative Percent \\
\hline Up to $20 \%$ & 32 & 27.1 & 78.0 & 78.0 \\
Up to $40 \%$ & 3 & 2.5 & 7.3 & 85.4 \\
Up to $60 \%$ & 5 & 4.2 & 12.2 & 97.6 \\
Up to $100 \%$ & 1 & 0.8 & 2.4 & 100.0 \\
Total & 41 & 34.7 & 100.0 & \\
Missing System & 77 & 65.3 & & \\
Total & 118 & 100.0 & & \\
\hline
\end{tabular}

We have investigated the extent to which event organizers support the development of domestic and inbound volunteer tourism. As we have found, the absolute majority of voluntourists are domestic $(97.50 \%)$. Foreign voluntourists usually take part in international and world events (e.g., World Championship in Ice Hockey). We note that in the case of events, the development of domestic volunteer tourism is mainly relevant.

There are different ways to reach potential voluntourists. Actually, the recruiting process consists of finding potential candidates by using personal contacts (37.80\%), social media networking $(20.70 \%)$, and web page for an organization or event $(12.20 \%)$ as the preferred methods of contact. In the case of big events with high demand on volunteers work, such as Pohoda festival, it is necessary to build a web page for volunteers or to address potential volunteers by posters and lectures in high schools and universities.

One aspect of the quality of volunteer management is repeated involvement of volunteers in the organization of events. The survey shows that while $29.30 \%$ voluntourists attended the event only once, more than two-thirds $(70.70 \%)$ of voluntourists participated in the events repeatedly. This means that volunteering at the event is important to them and motivates them to take part in the event again. The statistical connection between repeated volunteer work and the scale or type of event has not been statically proven (Sig. > 0.05).

An important part of volunteer management is to evaluate and appreciate volunteer work. Although volunteering is an unpaid activity, the organization should not take volunteers as a certainty and should have other opportunities for developing further cooperation. Many addressed organizations provided voluntourists with meals $(68.30 \%)$ and accommodation $(19.50 \%)$ or reimbursed their travel expenses $(2.60 \%)$. Looking at the research of Brozmanová Gregorová et al. [50], the reimbursement of part of their expenses is welcomed by the volunteers. As a sign of appreciation for the volunteer work addressed organizations offered to volunteers clothing with the event's logo $(34.10 \%)$, free tickets to the event for friends or family members $(34.10 \%)$, or promotional materials from event partners $(24.40 \%)$. These benefits were provided by $90.2 \%$ of respondents. 


\section{Conclusions and Discussion}

\subsection{Discussion}

Sustainability becomes a key challenge in developing quality tourism products without negatively affecting the natural and cultural environment that maintains and takes care of them [51]. Accentuating only one aspect (economic growth) is one of the main contemporary obstacles to making tourism more sustainable and enabling qualitative destination development [52]. The fastest growing alternative form of tourism that moves the goals of tourism away from for-profit forms is volunteer tourism.

Volunteer tourism, as a combination of individual interests of visitors in the tourism industry with a positive direct impact on society as well as the natural and economic environment, supports the development of solidarity and tolerance among volunteers and the community, and enables volunteers to gain experiences and skills to ensure their personal as well as professional growth. The combination of volunteering and tourism has various forms in practice. One of them is event volunteering.

Demand for volunteers is steadily rising to attract enthusiastic workers and optimize personnel costs, which can significantly affect the organizer's budget. Volunteers at organized events become an important factor that indirectly affect the sustainability of tourism in Slovak regions. Events with enormous attendance are also attended by foreign visitors what with awareness raising the international importance of the organized event and the region in which the event takes place. Presently, the number of event organizers is rising from year to year. Also, demands on the quality of organization and event's program are rising. Indeed, these factors support the competitiveness of events in a specific market segment. Organized events and their quality motivate potential visitors to decide to travel and participate in events.

Events organized by non-profit organizations have, according to research, influence not only on sustainable development of tourism on regional level, but also have influence on economic factors, raising awareness of social activity, strengthening local relationships, and preserving the local unique cultural and ethnic heritage of the community. These improvements in turn increase awareness of the region, its cultural attractions, and events [53-59].

Empirical analysis [53] proves that non-commercial regional events organized by non-profit organizations and public institutions can increase attendance in the tourism region. Similar results appear in the studies [60]. Attractiveness and frequency of events affect the loyalty of visitors' attendance on the event and stimulate their interest to participate in the event again in the future [53].

In connection with ecological side of the event, organized events are usually termed as non-ecological. There is an over production of waste, contribution to global warming, and so on. One event at which this research was conducted (Slovak music festival, Pohoda), won the highest prize at the European Festival Awards in category of The Green Operation Awards and became the most prestigious festival in Europe in 2017. At the festival, a mobile solar power plant and solar lighting of the area was used, other electricity was generated from a fixed network from a temporary substations. $0.22 \mathrm{~L}$ of fuel per participant was consumed, which represented $38 \%$ of the average consumption of fossil fuel per participant at festivals in Europe. They also provided waste sorting, reusable beer cups, and compostable dishes. Composting of compostable dishes took place directly at the event. There was also organized special separation of old toothbrushes. One visitor produces the same amount of waste on average as the daily average of waste produced per inhabitant in Slovakia. Furthermore, ecological sanitation was used. Drinking water was free of charge. By repairing the airport's water pipe (the site of the festival), a number of water tanks with drinking water and water for industrial purposes was eliminated. The ecological side has become a challenge for organizers of events to use ecological resources and apply ecological behavior.

Within the academic and scientific community, the debate over the sustainability of tourism development through any form of tourism can be very diverse and controversial. It is therefore morally necessary that organizers of not only commercial, but non-commercial events as well, take 
responsibility for their management of staff, volunteers, and organization of the event and encourage visitors and participants to act to achieve more sustainability in tourism.

This paper points to the situation of the examined problem in Slovakia, which has not been examined in terms of the relationship between organized events and volunteering in tourism with regard to the sustainability of tourism development yet. Initial research outputs have their pitfalls and deficiencies. The next stage of the survey will be to study the forms of sustainable tourism development, organized events, and volunteering, as well as their importance and value.

\subsection{Conclusions}

Events have become a significant part of destination tourism offers, they can increase visitor numberss, make a destination more attractive, and bring additional income. Despite growing interest in organized events due to population migration, cultural dislocation, stressful urban environments [59], and the rising trend of volunteering, the focus on event volunteering is in current literature only marginal. Therefore, the aim of the paper was to explore volunteer tourism in Slovakia from examples of organized events, especially to investigate exactly how event organizers support the development of domestic and inbound volunteer tourism in Slovakia. The research was based on the data from a questionnaire survey.

Out of 653 addressed events' organizers, less than a fifth were involved in the survey. Most of them collaborated with volunteers, creating proper circumstances for the volunteer tourism development. With the increasing scale of the event, the number of volunteers involved in the event's preparation and realization phase grows. Volunteers are particularly important in event organization mostly in the non-profit sector.

Half of addressed events' organizers work only with volunteers-local residents-while the other half also engages voluntourists and thus reassures the domestic volunteer tourism development. In case of an attractive event with greater than regional significance, the engagement of the voluntourists could be more distinct. The current situation has resulted from missing information about the management of volunteers, but it could be improved by an e-manual for event organizers providing an outline guide for volunteer management.

The volunteers' satisfaction can be seen in their repeated involvement in the organization of the event. The positive finding is that $70 \%$ of respondents declared mostly recurring cooperation with the same volunteers. It could be related with the benefits which organizers provide to voluntourists. According to the authors Heldt and Klerby [60], benefits-like the possibility to get tickets for events, promotional materials, or clothing with the event's logo-motivate the individuals to take part in events as volunteers. An important impulse for potential volunteers could be also the possibility to meet celebrities who participate in the event or the creation of a common group on social networks that would strengthen the motive of getting to know new people and creating new friendships.

Whereas in domestic and foreign literature there is no comprehensive study of volunteering at organized events, the results of the survey are perceived as the precondition of further studies of event volunteering in tourism and the creation of general recommendations for events' organizers.

Author Contributions: K.P., R.M., and L'.̌̌. collected the original data; K.P. and M.Ž. undertook the data analysis; K.P. and J.S. drafted the manuscript; and R.M. and L'.Š. refined the paper.

Acknowledgments: The support of the grant scheme research VEGA 1/0509/16 Perspectives of Development of Volunteer Tourism in Slovakia is acknowledged.

Conflicts of Interest: The authors declare no conflict of interest. 


\section{References}

1. Kontogeorgopoulos, N. Finding oneself while discovering others: An existential perspective on volunteer tourism in Thailand. Ann. Tour. Res. 2017, 65, 1-12. [CrossRef]

2. Polat, N.; Hermans, E. A model proposed for sustainable accessible tourism (SAT). TÉKHNE Rev. Appl. Manag. Stud. 2016, 14, 125-133. [CrossRef]

3. Mihalic, T. Sustainable-responsible tourism discourse-Towards 'responsustable' tourism. J. Clean. Prod. 2016, 111, 461-470. [CrossRef]

4. Mathew, P.V.; Sreejesh, S. Impact of responsible tourism on destination sustainability and quality of life of community in tourism destinations. J. Hosp. Tour. Manag. 2017, 31, 83-89. [CrossRef]

5. UNWTO; WYSE Travel Confederation. Global Report on the Power of Youth Travel. 2016. Available online: https://www.wysetc.org/wp-content/uploads/2016/03/Global-Report_Power-of-YouthTravel_2016.pdf (accessed on 6 April 2018).

6. Buffa, F. Young Tourists and Sustainability. Profiles, Attitudes, and Implications for Destination Strategies. Sustainability 2015, 7, 14042-14062. [CrossRef]

7. Benckendorff, P.; Moscardo, G.; Pendergast, D. Tourism and Generation Y; CAB International: Wallingford, UK, 2010; p. 170, ISBN 9781845936013.

8. Moscardo, G.; Benckendorff, P. Mythbusting: Generation Y and Travel. In Tourism and Generation Y; Benckendorff, P., Moscardo, G., Pendergast, D., Eds.; CAB International: Wallingford, UK, 2010; pp. 16-26, ISBN 9781845936013.

9. Clemmons, D. VolunTourism and the M3 travelers. Voluntourist 2008, 2. Available online: http://www. voluntourism.org/news-feature224.htm (accessed on 6 April 2018).

10. Lyons, K.D.; Wearing, S. Volunteer tourism as alternative tourism: Journeys beyond otherness. In Journeys of Discovery in Volunteer Tourism; Lyons, K.D., Wearing, S., Eds.; CABI: Cambridge, UK, 2008; pp. 3-11, ISBN 978-1-845-93380-7.

11. Chen, L.-J.; Chen, J.S. The motivations and expectations of international volunteer tourists: A case study of "Chinese Village Traditions". Tour. Manag. 2011, 32, 435-442. [CrossRef]

12. Clemmons, D. VolunTourism International Website. Available online: http://www.voluntourism.org (accessed on 17 September 2017).

13. Tomazos, K.; Butler, R.W. Volunteer tourism: The new ecotourism? Anatolia 2009, 20, 196-212. [CrossRef]

14. Wearing, S.; McGehee, N.G. International Volunteer Tourism. Intergrating Travellers and Communities; CABI: Oxford, UK, 2013; 172p, ISBN 978-1-84593-696-9.

15. Stainton, H. A segmented volunteer tourism industry. Ann. Tour. Res. 2016, 61, 213-267. [CrossRef]

16. Wearing, S.; Grabowski, S. Volunteer tourism and intercultural Exchange: Exploring the 'Other' in the experience. In Volunteer Tourism: Theory Framework to Practical Application; Benson, A.M., Ed.; Routledge: London, UK, 2011; pp. 193-210, ISBN 978-1-138-88356-7.

17. Taplin, J.; Dredge, D.; Scherrer, P. Monitoring and Evaluating Volunteer Tourism: A Review and Analytical Framework. J. Sustain. Tour. 2014, 22, 874-897. [CrossRef]

18. Uriely, N.; Reichel, A.; Ron, A. Volunteering in tourism: Additional thinking. Tour. Recreat. Res. 2003, 28, 57-62. [CrossRef]

19. Holmes, K.; Smith, K.M.; Lockstone-Binney, L.; Baum, T.G. Developing the dimensions of tourism volunteering. Leis. Sci. 2010, 32, 255-268. [CrossRef]

20. Lyons, K.D.; Wearing, S. Reflection on the Ambiguous Intersections between Volunteering and Tourism. Leis. Sci. 2012, 34, 88-93. [CrossRef]

21. Chobotová, M. Zhodnocení inovačního potencionálu neziskového sektoru v České republice. In XVIII. Mezinárodní Kolokvium o Regionálních Vědách. Sborník Př́spěvků; Klímová, V., Žítek, V., Eds.; Masarykova Univerzita: Brno, Czech Republic, 2015; pp. 405-412, ISBN 978-80-210-7861-1.

22. Svidroňová, $\mathrm{M}$. The role of non-profit organization in a regional development in a context of social cohesion: The case of Iceland. In XVII. Mezinárodní Kolokvium o Regionálních Vědách. Sbornik Příspěvků; Klímová, V., Žítek, V., Eds.; Masarykova Univerzita: Brno, Czech Republic, 2014; pp. 567-573, ISBN 978-80-210-6840-7. [CrossRef]

23. Morgan, J. Volunteer Tourism: What are the Benefits for International development? Voluntourist 2010, 6. Available online: http:/ / www.voluntourism.org/news-studyandresearch62.htm (accessed on 6 April 2018). 
24. Sin, H.L. Who are we responsible to? Locals'tales of volunteer tourism. Geoforum 2010, 41, $983-992$. [CrossRef]

25. Guttentag, D. Volunteer tourism: As good as it seems? Tour. Recreat. Res. 2011, 36, 69-74. [CrossRef]

26. Butcher, J. Volunteer Tourism May Not be as Good as It Seems. Tour. Recreat. Res. 2011, 36, 75-76. [CrossRef]

27. Tomazon, K.; Cooper, W. Volunteer tourism: At the crossroads of commercialization and service? Curr. Issues Tour. 2012, 15, 1-20. [CrossRef]

28. Smith, V.L.; Font, X. Volunteer tourism, greenwashing and understanding responsible marketing using market signalling theory. J. Sustain. Tour. 2014, 22, 942-963. [CrossRef]

29. Goodwin, H. Taking Responsibility for Tourism; Goodfellow Publishers: Oxford, UK, 2011; 256p, ISBN 978-1-06884-39-0.

30. Kotler, P.; Lee, N.R. Up and Out of Poverty: The Social Marketing Solution; Pearson Education: Upper Saddle River, NJ, USA, 2009; 341p, ISBN 10 0-13-714100-9.

31. Smith, K.A.; Lockstone-Binney, L.; Holmes, K.; Baum, T. Event Volunteering. International Perspectives on the Event Volunteering Experience; Routledge: New York, NY, USA, 2014; 230p, ISBN 978-0-415-82103-2.

32. Lopez, M.H. Volunteering Among Young People. CIRCLE Fact Sheet. 2004. Available online: https:/ / eric.ed. gov / ?id=ED485477 (accessed on 6 April 2018).

33. Tourism Research and Marketing. Volunteer Tourism: A Global Analysis; ATLAS: Arnhem, 2008; p. 83, ISBN 978-90-75775-34-1.

34. European Youth Portal. Volunteering in Europe. Available online: http://europa.eu/youth/eu/article/46/234_en (accessed on 6 April 2018).

35. NpfSynergy. Volunteering Trend Data. 2017. Available online: https://nfpsynergy.net/press-release/ volunteering-trend-data (accessed on 6 April 2018).

36. Downward, P.M.; Ralston, R.T. The sports development potential of sport event. Volunteering: Insights from the XVII Manchaster Commonwealth Games. Eur. Sport Manag. Quart. 2006, 6, 333-351. [CrossRef]

37. Ralston, R.; Lumsdon, L.; Downward, P. The third force in events tourism: Volunteers at the XVII Commonwealth Games. J. Sustain. Tour. 2005, 13, 504-519. [CrossRef]

38. Larson, M. Festival Innovation: Complex and Dynamic Network Interaction. Scand. J. Hosp. Tour. 2009, 9, 288-307. [CrossRef]

39. Zelinka, I.; Moreau, T.; Zhao, J. Toward zero waste events: Reducing contamination in waste streams with volunteer assistance. Waste Manag. 2018. [CrossRef] [PubMed]

40. Ahn, Y.-J. Recruitment of Volunteers Connected with Sports Mega-Events: A Case Study of the PyeongChang 2018 Olympic and Paralympic Winter Games. Available online: http:/ /ac.els-cdn.com/S2212571X16302670/ 1-s2.0-S2212571X16302670-main.pdf?_tid=9bb5735a-4b57-11e7-9979-00000aacb362\&acdnat=1496822710_ 9c26547f7fb2639c0531263802ccb787 (accessed on 15 July 2017).

41. Gallarza, M.; Arteaga, F.; Saura, I.G. The value of volunteering in special events: A longitudinal study. Ann. Tour. Res. 2013, 40, 105-131. [CrossRef]

42. Hallmann, K. Modelling the decision to volunteer in organised sports. Sport Manag. Rev. 2014, 18, 448-463. [CrossRef]

43. Kristiansen, E.; Skirstad, B.; Parent, M.; Waddington, I. 'We can do it': Community, resistance, social solidarity, and long-term volunteering at a sport event. Sport Manag. Rev. 2015, 18, 256-267. [CrossRef]

44. Lee, Y.; Kim, M.; Koo, J. The impact of social interaction and team member exchange on sport event volunteer management. Sport Manag. Rev. 2016, 19, 550-562. [CrossRef]

45. Laing, J. Festival and event tourism research: Current and future perspectives. Tour. Manag. Perspect. 2018, 25, 165-168. [CrossRef]

46. Getz, D.; Page, S.J. Progress and prospects for event tourism research. Tour. Manag. 2016, 52, 593-631. [CrossRef]

47. Wilson, J.; Arshed, N.; Shaw, E.; Pret, T. Expanding the Domain of Festival Research: A review and Research Agenda. Int. J. Manag. Rev. 2017, 19. [CrossRef]

48. Koutrou, N.; Papous, A.; Johnson, A. Post-Event Volunteering Legacy: Did the London 2012 Games Induce a Sustainable Volunteer Engagement? Sustainbility 2016, 8, 1221. [CrossRef]

49. Pompurová, K. Organizované Podujatia Ako Nástroj Dynamizácie Cestovného Ruchu; Vydavatel'stvo Univerzity Mateja Bela v Banskej Bystrici-Belianum: Banská Bystrica, Slovakia, 2014; 198p, ISBN 978-80-557-0779-2. 
50. Brozmanová Gregorová, A.; Adolfová, I.; Barancová Paulíková, M.; Bielešová, Z.; Gregorová, L’; Matejzelová, J.; Mojš, R.; Mračková, A.; Rossová, L.; Sujová, B.; et al. Štandardy Kvality Manažmentu Dobrovol'níkov a Dobrovol'níčok a Odporúčania na Prácu s Mládežou v Oblasti Dobrovol'níctva; Centrum Dobrovol'níctva, Platforma Dobrovol'níckych Centier a Organizácií: Banská Bystrica, Slovakia, 2014; p. 28.

51. Kunasekaran, P.; Gill, S.S.; Ramachandran, S.; Shuib, A.; Baum, T.; Herman Mohammad Afandi, S. Measuring Sustainable Indigenous Tourism Indicators: A Case of Mah Meri Ethnic Group in Carey Island, Malaysia. Sustainability 2017, 9, 1256. [CrossRef]

52. Paunović, I.; Jovanović, V. Implementation of Sustainable Tourism in the German Alps: A. Case Study. Sustainability 2017, 9, 226. [CrossRef]

53. Panfiluk, E. Impact of a Tourist Event of a Regional Range on the Development of Tourism. Procedia Soc. Behav. Sci. 2015, 213, 1020-1027. [CrossRef]

54. Crompton, J.L.; Lee, S.; Schuster, T.S. A guid for undertaking economic impact studies: The Springfest example. J. Travel Res. 2001, 40, 79-87. [CrossRef]

55. Thrane, C. Jazz festival visitors and their expenditures: Linking spending patterns to musical interest. J. Travel Res. 2002, 40, 281-286. [CrossRef]

56. Kim, S.S.; Petrick, P. Residents' perceptions on impacts of the FIFA 2002 World Cup: The case of Seoul as a host city. Tour. Manag. 2005, 26, 25-38. [CrossRef]

57. Rao, V. Celebrations as social investments: Festival expenditures, unit price variation and social status in rural India. J. Dev. Stud. 2001, 38, 71-97. [CrossRef]

58. Framke, W. The Destination as a Concept: A Discussion of the Business-related Perspective versus Sociocultural Approach in Tourism Theory. Scand. J. Hosp. Tour. 2002, 2, 92-108. [CrossRef]

59. Getz, D. Event Studies. Theory, Research and Policy for Planned Events, 2nd ed.; Routledge: New York, NY, USA, 2012; p. 442, ISBN 978-0-08-096953-4.

60. Heldt, T.; Klerby, A. Peace, love and well-being: Volunteering at the Peace \& Love Festival in Borlänge, Sweden. In Event Volunteering. International Perspectives on the Event Volunteering Experience; Smith, K.A., Lockstone-Binney, L., Holmes, K., Baum, T., Eds.; Routledge: New York, NY, USA, 2014; pp. 19-34, ISBN 978-0-415-82103-2.

(C) 2018 by the authors. Licensee MDPI, Basel, Switzerland. This article is an open access article distributed under the terms and conditions of the Creative Commons Attribution (CC BY) license (http://creativecommons.org/licenses/by/4.0/). 